\title{
Of mice and men, metals and mutations
}

\author{
D M DANKS
}

From the Birth Defects Research Institute, Royal Children's Hospital, Melbourne, Australia 3052.

This paper is based on the second Carter Memorial Lecture of the Clinical Genetics Society given in April 1985.

SUMmARY Several mutations affecting the transport of copper and zinc in humans and in mice have been discovered over the last 15 years, joining the long known disturbance of copper transport in Wilson's disease. Menkes' disease (classical and mild variant forms) and X linked Ehlers-Danlos syndrome (type IX, $X$ linked cutis laxa) have features in common with one another and with the brindled $\left(\mathrm{Mo}^{\mathrm{br}}\right)$ and blotchy $\left(\mathrm{Mo}^{\text {blo }}\right)$ mouse mutants, respectively. There may be one allelic series of mutants in each species or two loci may be involved in each. The toxic milk mutant (tx) in the mouse may be homologous to Wilson's disease in man. The defect of intestinal absorption of zinc in acrodermatitis enteropathica has no homologue yet in the mouse. However, the lethal milk (lm) mutant in the mouse may be homologous to a condition of zinc deficiency described in a few breastfed, low birth weight infants. Many more genetic defects of transport of copper and of zinc may await discovery. Conversely, these mutants are valuable in elucidating the normal processes of copper and zinc transport.

The topic of my lecture has been chosen primarily because it is my own special interest among the various areas of research in our Institute. However, I was also at some pains to choose a topic which seemed to me compatible with Cedric Carter's personality and interests. I wanted to give a lecture which he would have enjoyed, had he been in the audience.

Cedric Carter was a highly intelligent man and a great clinical geneticist. He had a wonderful memory which retained most of the things he had ever seen or read. He was very logical and quickwitted. Although he was not himself a laboratory worker, he was able to criticise basic scientific research in a penetrating way. He was efficient and businesslike, wasting few words and no time. He had a knack of making decisions and then moving on to the next subject without dwelling on the decision that he had made. Despite this, he had the important skill of 'second thinking'. By this, I mean his habit of returning to an important point in a discussion five or ten minutes later with a new contribution or a new thought. This was a characteristic he shared with Victor McKusick, the second of my mentors while training in clinical genetics. I found many similarities in these two men who were superficially so different in physique and in style. Apart from obvious similarities in intelligence, memory, and

Received for publication 20 September 1985 Accepted for publication 24 September 1985. broad perspectives in clinical genetics, they shared characteristics of reserve and apparent aloofness which really masked a warm friendliness.

Cedric always held his own point of view in a dogged and determined way, but he also respected a different point of view, provided that it was based upon good logic. His interest in today's topic would be different from mine. I am intrigued by the mutants I will discuss because of the potential they offer in helping me to understand how cells transport and use elements like copper and zinc. He would have been interested because of the complexity of the phenotypes and the intellectual attraction of a precise and logical explanation. In addition, his lasting interest in the careers of his protégés would have made him sit through my lecture and listen to it very carefully, out of sheer politeness!

My involvement in copper metabolism actually began when I was working with Cedric at Great Ormond Street in 1960. My planned study of heterozygotes for Wilson's disease was thwarted by the Medical Research Council's refusal to allow me to administer the dose of copper 64 that was needed for these studies. While a house officer in the Hospital, I had been involved in the early use of penicillamine in a young teenage girl who had presented in liver failure, but lived to rear a family of her own, thanks to John Walshe's discovery of this valuable drug.

When I returned to Australia, I continued an amateur interest in Wilson's disease and came to 
know a number of the scientists in CSIRO* Divisions in Melbourne who were working on different aspects of copper deficiency in sheep. This interest prepared my mind to recognise the relationship between Menkes' disease and copper deficiency.

\section{Menkes' disease, mottled mice, and related conditions}

Recognition of a series of babies with Menkes' disease between 1969 and 1971 allowed us to identify a number of additional features of the condition, and the combination suggested copper deficiency as a logical explanation of this pleiotropic syndrome. This was soon confirmed. ${ }^{12}$ Hypothermia, ${ }^{1}$ osteoporosis, ${ }^{13}$ elongation and tortuosity of cerebral ${ }^{3}$ and other arteries ${ }^{1}$ were the important new features. Recognition of the similarity of the arterial pathology ${ }^{1}$ to that seen in copper deficient pigs. ${ }^{4}$ was the final point that stimulated our copper studies. $^{2}$ Deficient disulphide bonding of hair keratin gave further support to the copper deficiency hypothesis ${ }^{5}$ since this feature was well known in copper deficient sheep.

Two years later, David Hunt, now at Queen Mary College, but then in Glasgow, provided an elegant analysis of the brindled mutation in the mouse ${ }^{6}$ showing parallel disturbances to those that we had demonstrated in Menkes' disease, and extending the range of observations because of the ease of access to tissues from multiple animals. In the intervening period the situation had been recognised as more complex than we had initially thought, with accumulation of unabsorbed copper in the intestinal mucosa, ${ }^{7}$ and also a substantial accumulation of copper in the kidney. The failure of injections of copper to cure the disease had made us suspect something more than simple copper deficiency.

Today the brindled mouse is regarded as the best understood pleiomorphic mutation in the mouse,

*Commonwealth Scientific and Industrial Research Organisation. and Menkes' disease could probably claim a comparable status in the human. Nonetheless, I find the deficiencies in our knowledge about these two mutations an extreme disappointment. Back in 1975 it seemed that we had everything on our side in working out the basic defect. We had phenotypic expression in cultured fibroblastic cells, ${ }^{78}$ and we had a model in the mouse. I underestimated the difficulties that would occur because copper has only a very short lived isotope $\left({ }^{64} \mathrm{Cu}\right.$, half life 12 hours) which is generally made with low specific activity, and a slightly longer lived isotope $\left({ }^{67} \mathrm{Cu}\right.$, half life 60 hours) which has been available only intermittently and at high cost. The unfortunate tendency of copper to associate non-specifically with many proteins and to dissociate from specific binding with proteins under separative conditions like electrophoresis has also proved a problem.

We can give a reasonable explanation of the phenotypic features of the disease by describing the functions of copper dependent enzymes. ${ }^{9-11}$ The bone, connective tissue, and arterial disease are readily explained by deficiency of the copper enzyme, lysyl oxidase, ${ }^{12}$ required for cross linking of both collagen and elastin. The depigmentation of skin and hair is the result of deficiency of the copper enzyme tyrosinase. ${ }^{13}$ We know that disulphide bonding in keratin requires copper, although we do not know what enzyme carries out this process. One might blame the hypothermia on cytochrome oxidase deficiency or inadequate production of catecholamines. There are a number of possible culprits for the brain damage: deficiency of catecholamine or excess of dopamine and its by-products because of dopamine $\beta$ hydroxylase deficiency ${ }^{14}{ }^{15}$; cytochrome oxidase deficiency ${ }^{15}$; or oxygen free radical damage because of superoxide dismutase deficiency ${ }^{15}$ (table 1).

One mystery is the absence of anaemia and neutropenia in Menkes' disease ${ }^{1}$ and brindled mice,$^{16}$ constant features of nutritional copper deficiency in $\operatorname{man}^{17}$ and animals. ${ }^{10}$

TABLE 1 Copper concentrations, copper enzyme activities, and levels of copper enzyme products in brindled mouse tissues (percentage of litter mate controls).

\begin{tabular}{|c|c|c|c|c|c|}
\hline & Liver & Kidney & Heart & Brain & Skin \\
\hline Copper concentration ${ }^{15}+$ & 20 & 350 & 50 & 25 & 60 \\
\hline $\begin{array}{l}\text { Superoxide dismutase } \\
\text { activity } 15 \\
\text { Cytochrome } \mathrm{C} \text { oxidase }\end{array}$ & 100 & 100 & 75 & 70 & - \\
\hline $\begin{array}{l}\text { Cytochrome C oxidase } \\
\text { activity }^{15}\end{array}$ & 110 & 100 & 44 & 28 & - \\
\hline $\begin{array}{l}\text { Noradrenaline concentration } \\
\text { (product of dopamine } \beta \text { hydroxylase) }\end{array}$ & - & - & - & 25 & - \\
\hline Lysyl oxidase activity ${ }^{42}$ & - & - & - & - & 55 \\
\hline Tyrosinase activity ${ }^{13}$ & - & - & - & - & 0 \\
\hline
\end{tabular}

- Not relevant to measure.

-Not relevant to measure.
†These results apply specifically to Dr Phillips's ${ }^{15}$ and Dr Royce's ${ }^{42}$ data, but can be taken as a guide for Dr Holtein's ${ }^{13}$ data. 


\section{Tissue distribution of copper}

It is when we come to explain the cause of the copper deficiency and the maldistribution of copper in body tissues that we run into difficulties. In Menkes' disease and brindled mice, the reduction in tissue copper is severe in the liver and brain and moderate in most other tissues, with the notable exceptions of intestinal mucosa, kidney, and testes, where greatly raised levels of copper are found. ${ }^{11}$ Prenatally, one finds low copper levels in the liver, but moderately raised levels of copper in all other tissues, including placenta. ${ }^{18-20}$ The fetal observations suggest that the basic phenotype in all tissues except the liver is one of acquisition of excessive amounts of copper. A general copper deficiency is superimposed postnatally, because retention of copper in intestinal mucosal cells reduces absorption, and retention in the kidney tubules further limits availability. Transfer of copper across the placenta is less severely affected. ${ }^{20}$

Fibroblastic, lymphoid, and renal epithelial cells have been cultivated from either humans or mice and have shown a phenotype of excessive copper accumulation, ${ }^{21}$ which differs from normal most strikingly when media with a low copper content are used (figure).$^{22}$ Lysyl oxidase activity is reduced in these cells despite the copper accumulation and cannot be restored by addition of copper to the medium or homogenate. ${ }^{12}$

\section{Basic defect}

The most simple explanation of these phenotypic

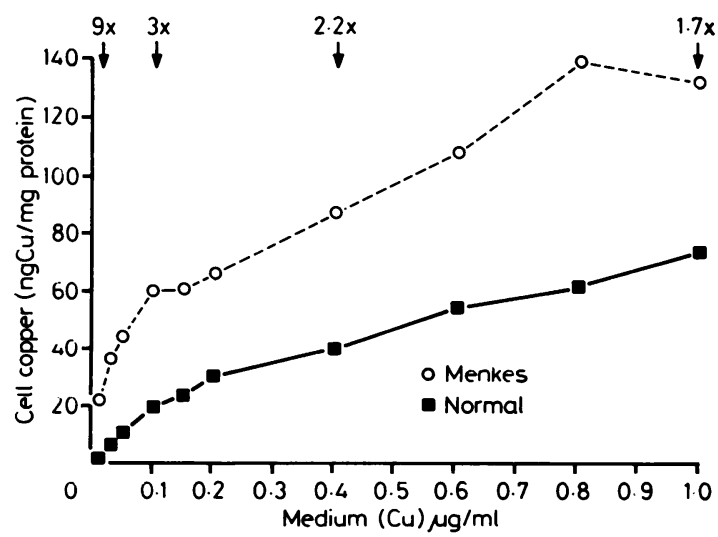

FIGURE Copper isotope accumulated in continuous lymphoid cell cultures incubated for 20 hours in media with the copper contents indicated, expressed as ng copper/mg protein by calculation utilising the measured specific activity of the isotope. features would be a mutation causing some intracellular copper binding protein to show increased avidity to copper, ${ }^{23}$ so that it scavenges all the copper and leaves little available for copper enzyme synthesis. Binding copper to this protein in cells with good access to copper (interstitial mucosa, kidney) would deprive other tissues. It could be argued that the liver is spared the primary effects of the mutation and shows only secondary copper deficiency. ${ }^{23}$

Many studies in cells ${ }^{22}$ and mouse tissues ${ }^{24}$ have shown that the excess copper is bound to metallothionein. Consequently, a structural mutation of metallothionein would be a first candidate. This can be ruled out in these $X$ linked conditions now that the metallothionein genes have been localised in the human on chromosome $16 \mathrm{q},{ }^{25}{ }^{26}$ and in the mouse on chromosome $8 .^{27}$

Another hypothesis might suggest a controlling locus on the $X$ chromosome causing constitutive overproduction of metallothionein. Studies by members of our group have shown that metallothionein messenger RNA levels are not raised in the kidneys of the mutant animals despite the very high copper content of this tissue. Levels of metallothionein mRNA in continuous lymphocyte cultures (CLC) were found to respond to progressive addition of copper to the medium. ${ }^{28}{ }^{29}$ Constitutive overproduction of metallothionein can be dismissed as the basic cause. Indeed, it seems probable that the involvement of metallothionein is secondary rather than primary.

One might postulate a defect which increases the entry of copper to the cells leading to over-induction of metallothionein to cope with the accumulating copper. Measurements of the initial rate of uptake into CLCs have given normal results in our laboratory ${ }^{30}$ and others.

Copper isotope has been shown to accumulate in abnormal amounts over 24 hours of culture in isotope containing medium. ${ }^{19}{ }^{21}$ The loss of isotope during a further 24 hours' growth in a medium containing no isotope is greatly reduced. ${ }^{21} \mathrm{~A}$ defect in efflux might be proposed, but to measure efflux we must know the size of the intracellular pool from which copper is effluxing, and the specific activity of isotope in the pool.

Studies in hepatocyte suspensions have shown a plateau in uptake of copper isotope at 40 minutes. ${ }^{31}$ By assuming an equilibrium between the easily exchangeable intracellular pool and the medium at this point, efflux has been measured over short periods. Normal CLCs show a similar phenomenon, although the plateau at 40 minutes is less definite than that using hepatocytes, and even less definite in Menkes' CLCs. Calculation of efflux on this 
assumption gave a higher rate of efflux from the mutant cells than from normal cells. ${ }^{30}$ However, there is reason to doubt the validity of the assumption underlying this method for the mutant CLCs.

My present hypothesis to explain all of these findings involves postulating a copper carrier within cells which normally makes copper available to copper enzymes. Copper bound to this carrier would not induce metallothionein synthesis. Deficiency of this carrier protein in the mutant cells would reduce the availability of copper to the copper enzymes and allow any copper entering the cells to bind to metallothionein and to induce further synthesis.

One might postulate that normal cells should show features of the Menkes' phenotype if subjected to very high concentrations of copper in the culture medium, because the binding capacity of the putative intracellular protein would be exceeded and the metallothionein would then be induced by any additional copper that is absorbed. These results have been observed. ${ }^{30}$

One important reservation must be expressed about all the results regarding copper transport in cultured cells, because the copper isotopes have been presented to the cells as inorganic salts in balanced salt solutions or as copper-amino acid complexes in protein free media a little more complex. Experiments with hepatoma cells or liver cell suspension have shown that albumin retards the uptake of copper very greatly when present in molar concentrations which exceed the copper ion levels, ${ }^{32}$ as is the case in plasma in the intact human or animal. We do not know the physiological mode of presentation of copper to other body cells, but its use might drastically alter the results obtained in normal and mutant cells. Caeruloplasmin is a candidate for this role.

In summarising many man and woman years of research in our group and in four or five other groups around the world that have been studying these mutations intensively, I have freely mixed observations made in human tissues and cells with those made in tissues and cells of brindled and blotchy mice. It is legitimate to question the assumption that the human and mouse loci are homologous and that all of the mouse mutants are allelic.

\section{Are the mutants allelic?}

Before proceeding to consider this question I will list the mouse mutations that are known. ${ }^{11}{ }^{33}$ These are shown in table 2 . The phenotypes in the affected male range from lethality in utero in the mottled mutant itself through to long term survival in the blotchy variant. Note that the more rapidly lethal mutants all produce neurological disturbance and no arterial disease, whereas arterial disease and emphysema dominate the picture in the blotchy mutant, which does not show any neurological disturbance.

In the human, we know the classical Menkes disease, which is generally lethal by 3 years of age, ${ }^{9}$ and a mild variant which has been described in one Australian boy who presented at 2 years of age with pili torti and gross cerebellar dysfunction. ${ }^{9}{ }^{34} \mathrm{He}$ is alive and quite healthy at the age of 7 years, having been treated with copper histidine injections for most of the intervening years. He still has mild hair abnormalities and marked cerebellar ataxia, but he is intellectually normal. Arterial dilatation and elongation were present at presentation, but he has not been reviewed by arteriography since. Of course, we cannot tell whether his good progress has been brought about by treatment or whether this might be the natural history of this mild variant

A further related human mutant has been recognised more recently. Very similar phenotypes have been described under the names of $\mathrm{X}$ linked Ehlers-Danlos syndrome and $\mathrm{X}$ linked cutis laxa. It

TABLE 2 Phenotype characteristics of alleles at the $X$ linked mottled locus of the mouse.

\begin{tabular}{|c|c|c|}
\hline Allele & Male hemizygote & Female heterozygote \\
\hline $\begin{array}{l}\text { Blotchy } \\
\left(\mathrm{Mo}^{\text {blo }}\right)\end{array}$ & $\begin{array}{l}\text { Pale fur, curly whiskers } \\
\text { Viable and fertile }\end{array}$ & $\begin{array}{l}\text { Variegated coat colour, curly whiskers } \\
\text { Viable and fertile }\end{array}$ \\
\hline $\begin{array}{l}\text { Brindled } \\
\left(\mathrm{Mo}^{\mathrm{br}}\right)\end{array}$ & $\begin{array}{l}\text { Pale fur, curly whiskers } \\
\text { Lethal between } 13 \text { and } 16 \text { days } \\
\text { post partum }\end{array}$ & $\begin{array}{l}\text { Variegated coat colour, curly whiskers } \\
\text { Viable and fertile }\end{array}$ \\
\hline $\begin{array}{l}\text { Dappled } \\
\left(\mathrm{Mo}^{\mathrm{dp}}\right)\end{array}$ & $\begin{array}{l}\text { Pale fur, curly whiskers } \\
\text { Skeletal defects } \\
\text { Lethal at birth }\end{array}$ & $\begin{array}{l}\text { Variegated coat colour, curly whiskers } \\
\text { Skeletal defects } \\
\text { Viable and fertile }\end{array}$ \\
\hline $\begin{array}{l}\text { Mottled } \\
\text { (Mo) }\end{array}$ & Lethal in utero & $\begin{array}{l}\text { Variegated coat colour, curly whiskers } \\
\text { Viable and fertile }\end{array}$ \\
\hline
\end{tabular}


is not yet clear whether there is truly one entity or two. Skin laxity is obvious. Joint laxity is mild and presentation is in childhood or adult life because of inguinal hernias, joint disorders, and sometimes recurrent urinary tract infections related to bladder diverticulae. ${ }^{35-37}$ A primary deficiency of lysyl oxidase was initially claimed, ${ }^{38}$ but this claim was subsequently withdrawn and it is now apparent that the deficiency of this enzyme is secondary to a disturbance of copper transport with mildly reduced serum copper, ${ }^{35}$ and abnormalities in cultured cells which are indistinguishable from those seen in Menkes' disease. ${ }^{36} 37$ No studies on tissue copper levels have yet been published, nor is there adequate documentation about the hair, although this has been assumed to be normal. Effects of copper treatment have not been reported. Our own studies on cells referred from families in other countries suggest that alterations of cellular copper transport are not found in all families. ${ }^{39}$

We are therefore faced with six $\mathrm{X}$ linked mutants with very similar phenotypes in the mouse and at least three $\mathrm{X}$ linked phenotypes with closely related features in the human.

The mouse geneticists working on this subject have assumed that the various mouse mutants are allelic, but stringent proof is lacking. The similarity of the phenotypes in the hemizygous males and in the heterozygous females is some evidence in this direction. The fact that doubly heterozygous females have phenotypes very similar to homozygous males has also been used as evidence. However, interpretation is confused by $\mathrm{X}$ chromosome inactivation, for each cell is hemizygous for one or other mutation, whether the genes are allelic or not, granted that both are $\mathrm{X}$ chromosomal. No-one has bred enough of these doubly heterozygous animals to have any chance of seeing a cross over in the progeny. One recombinant would disprove allelism, but enormous numbers of non-recombinant progeny would be needed to dismiss an alternative hypothesis of closely linked loci controlling sequential steps in copper transport.

Linkage studies have mapped all of the mouse mutants to the same locus, but this is a fairly crude statement when one remembers the number of offspring generally used in linkage experiments in the mouse. These numbers are certainly inadequate to distinguish between allelism and adjacent loci.

The only way of proving or disproving allelism, short of actually identifying the gene products, would be by examination of the phenotype in tetraploid hybrid cells. We are planning these experiments, but are still trying to isolate cell lines with appropriate resistance markers for some of them. We have been able to show that the phenoty- pes are sufficiently recessive in tissue culture to make such hybridisation experiments feasible. ${ }^{40}$ It has been very difficult to do these studies with the low specific activity copper 64 generally available, but we now have high specific activity copper 64 .

Most of the mouse mutants seem to form a graded series in the severity of the same features. However, blotchy $\left(\mathrm{Mo}^{\text {blo }}\right)$, the least severe, shows a qualitative difference from the others, in that connective abnormalities are much more pronounced than in any of the other mutants ${ }^{41}$ and lysyl oxidase levels are more severely reduced than in the brindled strain, ${ }^{42}$ which otherwise shows more severe disturbances of copper transport in tissue culture. $\mathrm{X}$ linked cutis laxa seems to show a similar qualitative difference from the two forms of Menkes' disease. One might wonder about the possibility of homology between blotchy and $X$ linked cutis laxa on the one hand, and between brindled and the two forms of Menkes' disease on the other hand, with the two sets of loci being closely linked, rather than identical.

Hopefully the next few years will see better progress in understanding these frustrating conditions.

\section{Related conditions}

Several other disturbances of copper status have been described in individual families and remain uninterpretable pending further evaluation of these families or discovery of other similar families or both.

Willemse $e a^{43}$ described a boy with an $\mathrm{X}$ linked clinical disease indistinguishable from Menkes' disease with similar pathological changes and copper results in blood, urine, and tissues. He differed in showing near normal intestinal absorption of copper and much less copper bound to metallothionein in cultured cells than one finds in Menkes' disease.

Haas et $^{a l^{44}}$ described two male cousins related through their mothers who suffered mental retardation with progressive decerebrate posturing and athetosis. Oral absorption of copper was grossly diminished although intravenous doses were incorporated into caeruloplasmin normally. A gross disparity in the liver copper results reported in the two boys is disturbing.

Mehes and Petrovicz ${ }^{45}$ reported benign copper deficiency with $\mathrm{X}$ linked or autosomal dominant inheritance. Fair hair, widened metaphyses, mild anaemia, and seizures which responded to oral copper therapy were features in the index case. A disparity between serum copper and caeruloplasmin levels was hard to explain in this report.

One must anticipate a series of steps in cellular 
copper transport, and several different genetic diseases caused by defects in these steps must be expected. Copper deficiency should be considered in patients with any two or more features which could be explained by faults in copper enzymes.

\section{Wilson's disease and related conditions}

The involvement of copper in the pathogenesis of Wilson's disease has been known for many years, but very little has been discovered about the basic defect. The best that we can say is that the defect must involve some process which is important in the production of caeruloplasmin and in the biliary excretion of copper. ${ }^{911}$ Most of the other consequences of the disease seem to flow from these two primary disturbances, especially from the excretory failure.

Progress has been very slow because there has been no way of studying the disease in cell culture and because there has been no animal model. Recently, several groups have shown rather inconsistent, but frequently repeated abnormalities in the handling of copper by cultured fibroblastic cells. ${ }^{46-48}$ We now feel that we have a more consistent phenotype which is ready for further studies.

Many Bedlington terriers show a recessively inherited defect causing gross copper accumulation in the liver, with episodes of acute liver damage and acute haemolysis in the late stages which are very like the acute crises seen in Wilson's disease. ${ }^{49-51}$ The situation in these homozygous mutants is modified by the deficient copper binding capacity of albumin in all dogs. This allows copper to enter the liver more rapidly after oral ingestion.

Normal sheep also show some features resembling those of Wilson's disease. Biliary excretion of copper and incorporation of copper into caeruloplasmin are less efficient in sheep than in rats or humans. ${ }^{52} \mathrm{We}$ wondered whether sheep metallothioneins might differ significantly from those of other species. The amino acid sequence deduced from the cloned MTI cDNA differs little from the mouse and human proteins. ${ }^{53}$

The toxic milk mouse appears to be a model of Wilson's disease according to the results published by Rauch ${ }^{54}$ It is very frustrating that this mutant, first mentioned in the Mouse Newsletter in 1977, remains unavailable to the large number of research groups around the world who are interested in copper transport. The phenotype to which the name is given actually occurs in the pups of homozygous mutant adult females. These pups die of copper deficiency if fed their mother's milk which contains very little copper. The homozygous animals accumulate copper in liver and kidney and develop damage to these organs later in life, thereby resembling Wilson's disease. No measurements of copper content of breast milk in women with Wilson's disease have been published.

Hepatic copper accumulation has been described in a number of other forms of liver disease. ${ }^{9}$ In many of these diseases we may merely be witnessing the consequences of non-specific interference with the biliary excretion of copper, the main method of disposal of copper from the body. Primary biliary cirrhosis probably fits into this category although the extremely high hepatic copper levels encountered suggest a special form of secondary disturbance of copper excretion. Indian childhood cirrhosis seems to cause the most extreme copper retention described in humans and some rather specific disturbance of copper excretion seems likely even if one were to accept the high copper intakes that are claimed. Åagenes' syndrome also causes severe copper retention. Some of these diseases may yet prove to involve primary disturbances of hepatic copper transport.

Two different neurological disturbances with some resemblance to Wilson's disease have been claimed to show significant copper overload, ${ }^{55}{ }^{56}$ but inconsistencies in the copper results cast some doubt on these reports.

Clinicians need to keep copper accumulation in mind in diseases which affect liver, brain, or kidneys, and especially when two or more of these organs are affected. Wilson's disease is probably not the only such condition.

\section{Mutations affecting zinc transport}

ACRODERMATITIS ENTEROPATHICA

Acrodermatitis enteropathica of humans was the first genetic disease affecting zinc to be described. ${ }^{57}$

The defect interferes with intestinal absorption of zinc, but zinc appears to be utilised quite normally once absorbed. Consequently, the clinical problem is readily overcome by oral administration of larger than normal amounts of zinc. Interactions between plasma zinc and tissue zinc are so complex and so labile that one should not be surprised at finding normal plasma zinc levels in some samples from untreated cases of this disease. A similar condition has been described in Friesian cattle. ${ }^{58}$

The second type of mutation affecting zinc transport was described first in the mouse and secondly in the human. This mutation is known as lethal milk in the mouse. ${ }^{59}$ It is an interesting genetic situation similar to the toxic milk described above, for the phenotype is observed in the offspring (heterozygous) of the genetically abnormal dam (homozygous), affected by this autosomal recessive disorder. The secretion of zinc into the breast milk is reduced 
and the pups die of zinc deficiency. They can be rescued by fostering to a normal mother. Reverse fostering of normal pups onto the affected dam leads to zinc deficiency in these pups. No disturbance of zinc distribution in other parts of the body has been described, but to date the documentation of this mutant is very limited.

Quite recently several groups have described very small premature babies who have developed acrodermatitis while breast fed and the milk of these mothers has been shown to be deficient in zinc. ${ }^{60}$ It seems very probable that this is a homologue to the mouse mutation, but there is no real genetic information to support this contention. The genetic situation would be rather novel. One would expect to find that one in four of the sisters of a woman whose baby suffered from this problem would also have zinc deficient milk. Clinical manifestations in the babies seem to require both the abnormal milk and severe prematurity. Of course, the phenotype might be established by measurement of the milk zinc levels in the sisters of an affected woman, but even this is a rather cumbersome form of genetic investigation, for one has to wait until the sister is lactating to make the assessment.

\section{Mutants affecting other trace elements}

I have chosen not to regard the various mutations affecting vitamin $B_{12}$ metabolism as mutants affecting cobalt transport in the body. The absorption and modification of vitamin $B_{12}$ does not really rank as transport or metabolism of cobalt, which must be complexed in an organic molecule before it can be absorbed.

One might argue that the same is true of the molybdenum cofactor disease which has been described in recent years, but the novelty of molybdenum as a source of disease and of this condition warrants a few words. These patients have xanthine oxidase and sulphite oxidase deficiency, the latter being primarily responsible for the phenotype of severe mental retardation. The actual mutation is in the pterin cofactor which binds molybdenum, rather than any aspect of molybdenum uptake and transport. ${ }^{61}$ The pterin cofactor is thought to be synthesised in the body rather than absorbed intact. Presumably there is a process which allows absorption of molybdenum and incorporation into the cofactor.

The mutations affecting trace element transport which I have been able to describe must be just the 'tip of an iceberg'. There must be many specific steps in the absorption, transport, and elimination of each trace element. Each process must be controlled by genes and each gene must be subject to mutation.
The work of our own research group which is included in this review has involved many scientists, research students, and research assistants in the Royal Children's Hospital and in the Departments of Paediatrics and Genetics of the University of Melbourne over the last 14 years. Most are specifically acknowledged by citations in the references especially in regard to recent unpublished results. The special contribution of Dr Jim Camakaris has been particularly appreciated. The work has been supported by the National Health and Medical Research Council, the Royal Children's Hospital Research Foundation, and the University of Melbourne.

\section{References}

${ }^{1}$ Danks DM, Campbell PE, Stevens BJ, Mayne V, Cartwright E. Menkes' kinky hair syndrome: an inherited defect in copper absorption with widespread effects. Pediatrics 1972;50:188-201.

2 Danks DM, Stevens BJ, Campbell PE, et al. Menkes' kinky-hair syndrome. Lancet 1972;i:1100-3.

3 Wesenberg RL, Gwinn JL, Barnes GR. Radiological findings in the kinky-hair syndrome. Radiology 1969;92:500-6.

4 Carnes WH. Role of copper in connective tissue metabolism. Fed Proc 1971;30:995-1000.

5 Gillespie JM. Keratin structure and changes in copper deficiency. Aust J Dermatol 1973;14:127-31.

6 Hunt DM. Primary defect in copper transport underlies mottled mutants in the mouse. Nature 1974;249:852-4.

7 Danks DM, Cartwright E, Stevens BJ, Townley RRW. Menkes' kinky hair disease: further definition of the defect in copper transport. Science 1973;179:1140-1.

${ }^{8}$ Danks DM. Steely hair, mottle mice and copper metabolism. $N$ Engl J Med 1975;293:1147-9.

9 Danks DM. Hereditary disorders of copper metabolism in Wilson's disease (hepatolenticular degeneration) and Menkes' (steely-hair) disease. In: Stanbury JB, Wyngaarden JB, Fredrickson DS, Goldstein JL. Brown MS, eds. The metabolic basis of inherited disease. New York: McGraw-Hill, 1983:1251-68.

10 Danks DM. Copper deficiency in humans. In: Biological roles of copper. Ciba Foundation Symposium 79. Amsterdam: Excerpta Medica, 1980:209-25.

1 Danks DM, Camakaris J. Mutations affecting trace elements. In: Harris H, Hirshhorn K, eds. Advances in human genetics. New York: Plenum Press, 1983:149-216.

12 Royce PM. Camakaris J, Danks DM. Decreased lysyl oxidase activity in skin fibroblasts from patients with Menkes' syndrome. Biochem J 1980;192:579-86.

13 Holstein TJ, Fung RQ, Quevedo WC Jr, Bienieki TC. Effect of altered copper metabolism induced by mottled alleles and diet on mouse tyrosinase (40662). Proc Soc Exp Biol Med 1979;162:264-8.

${ }^{14}$ Grover WD, Kenkin RI, Schwartz M, Brodsky N, Hobdeli E, Stolk JM. A defect in catecholamine metabolism in kinky-hair disease. Ann Neurol 1982;12:263-66.

15 Phillips M. Unpublished data.

16 Mann JR. Camakaris J, Francis N, Danks DM. Copper metabolism in mottled mouse mutants: studies of blotchy $\left(\mathrm{Mo}^{\text {blo }}\right)$ mice and a comparison with brindled ( $\left.\mathrm{Mo}^{\mathrm{br}}\right)$ mice. Biochem J 1981;196:81-8.

17 Graham GG. Cordano A. Copper depletion and deficiency in the malnourished infant. Johns Hopkins Med J 1969;124:139 50 .

18 Heydorn K, Damsgaard E, Horn N, et al. Extra-hepatic storage of copper: a male foetus suspected of Menkes' disease. Humangenetik 1975;29:171-5. 
${ }^{19}$ Horn N. Menkes' X-linked disease: prenatal diagnosis of hemizygous males and heterozygous female. Prenat Diag 1981:1:107-20

${ }^{20}$ Mann JR, Camakaris J, Danks DM. Copper metabolism in mottled mouse mutants: defective placental transfer of ${ }^{64} \mathrm{Cu}$ to foetal brindled $\left(\mathrm{Mo}^{\mathrm{br}}\right)$ mice. Biochem J 1980;186:629-31.

${ }^{21}$ Camakaris J, Danks DM, Ackland L, Cartwright E, Borger P, Cotton RGH. Altered copper metabolism in cultured cells from human Menkes' syndrome and mottled mouse mutants. Biochem Genet 1980;18:117-31.

22 Riordan JR, Jolicoeur-Paquet L. Metallothionein accumulation may account for intracellular copper retention in Menkes' disease. J Biol Chem 1982;257:4639-45.

23 Danks DM. Copper transport and utilisation in Menkes' syndrome and in mottled mice. Inorg Perspect Biol Med 1977;1:73-100

${ }^{24}$ Prins HW, Van den Hamer CJA. Abnormal copper-thionein synthesis and impaired copper utilization in mutated brindled mice: model for Menkes' disease. J Nutr 1980;110:151-7.

${ }^{25}$ Karin M, Eddy RL, Henry WM, Haley LL, Byers MG, Shows TB. Human metallothionein genes are clustered on chromosome 16. Proc Natl Acad Sci USA 1984;81:5494-8.

26 Schmidt CJ, Hamer DH, McBride OW. Chromosomal location of human metallothionein genes: implications for Menkes' disease. Science 1984;224:1104-6.

${ }^{27}$ Cox DR, Palmiter RD. Assignment of the mouse metallothionein-I (Mt-I) gene to chromosome 8: implications for human Menkes disease. Hum Genet 1983;64:61-4

${ }^{2 *}$ Stevenson T. Unpublished data.

${ }^{29}$ Lione A, Pavlakis GN, Hamer DH. Menkes' disease: abnormal metallothionein gene regulation in response to copper. Cell 1985;40:301-9.

30) Herd S. Unpublished data.

${ }^{31}$ Darwish HM, Schmitt RC, Cheney JC, Ettinger MJ. Copper efflux kinetics from rat hepatocytes. Am J Physiol 1984;246:G48-55.

32 van den Berg GJ, van den Hamer CJA. Trace metal uptake in liver cells. I. Influence of albumin in the medium on the uptake of copper by hepatoma cells. J Inorg Biochem 1984;22:73-84.

${ }^{33}$ Green MC, ed. Genetic variants and strains of the laboratory mouse. Stuttgart: Gustav Fisher Verlag, 1981.

${ }^{34}$ Procopis P, Camakaris J, Danks DM. A mild form of Menkes' syndrome. J Pediatr 1981;98:97-9.

35 Byers PH, Siegel RC, Holbrook KA, Narayanan AS, Bornstein $P$, Hall JG. X-linked cutis laxa; defective cross-link formation in collagen due to decreased lysyl oxidase activity. $N$ Engl J Med 1980;303:61-5

${ }^{36}$ Kuivaniemi H, Peltonen L, Palotic A, Kaitila I, Kivirikko KI. Abnormal copper metabolism and deficient lysyl oxidase activity in a heritable connective tissue disorder. J Clin Invest 1982;69:730-3.

${ }^{37}$ Peltonen L, Kuivaniemi H, Palotic A, Horn N, Kaitila I, Kivirikko KI. Alterations in copper and collagen metabolism in the Menkes syndrome and a new subtype of the Ehlers-Danlos syndrome. Biochemistry 1983;22:6156-63.

${ }^{36}$ Di Ferrante N, Leachman RD, Angelini P. Lysyl oxidase deficiency in Ehlers-Danlos syndrome type V. Connect Tissue Res 1975;3:49-53.

${ }^{34}$ Camakaris J. Unpublished data.

40) Brown RM, Camakaris J. Danks DM. Observations on the Menkes' and brindled mouse phenotypes in cell hybrids. Somatic Cell Genet 1984;10:321-30.

4 Rowe DW, McGoodwin EB, Martin GR, Grahn D. Decreased lysyl oxidase activity in the aneurysm-prone mottled mouse. $J$ Biol Chem 1977;252:939-42.

42 Royce PM, Camakaris J, Mann JR, Danks DM. Copper metabolism in mottled mouse mutants: the effect of copper therapy on lysyl oxidase activity in brindled $\left(\mathrm{Mo}^{\mathrm{br}}\right)$ mice. Biochem $J$ 1982:202:369-71.

${ }^{43}$ Willemse J, van den Hamer DJA, Prins HW, Jonker PL.
Menkes' kinky hair disease. I. Comparison of classical and unusual clinical and biochemical features in two patients. Brain Dev 1982;4:105-14.

44 Haas RH, Robinson A, Evans K, Lascelles PT, Dubowitz V. An $\mathrm{X}$-linked disease of the nervous system with disordered copper metabolism and features differing from Menkes' disease Neurology (Minneap) 1981:31:852-9.

${ }^{45}$ Mehes K, Petrovicz E. Familial benign copper deficiency. Arch Dis Child 1982;57:716-8.

${ }^{46}$ Goka TJ, Stevenson RE, Hefferan PM, Howell RR. Menkes' disease. A biochemical abnormality in cultured human fibroblasts. Proc Natl Acad Sci USA 1976;73:604-6.

${ }^{47}$ Chan YW, Garnica AD, Rennert OM. Cell culture studies in Menkes' kinky hair disease. Clin Chim Acta 1978;88:495-507.

${ }^{48}$ Camakaris J, Ackland L, Danks DM. Abnormal copper metabolism in cultured fibroblasts from patients with Wilson's disease. J Inher Metab Dis 1980;3:155-7.

49 Twedt DC, Sternlieb I, Gilbertson SR. Clinical, morphologic, and chemical studies on copper toxicosis of Bedlington terrier. $J$ Am Vet Med Assoc 1979;175:269-75.

50 Su LC, Ravanshad S, Owen CA Jr, McCall JT, Zollman PE, Hardy RM. A comparison of copper-loading disease in Bedlington terriers and Wilson's disease in humans. Am J Physio 1982;243:G226-30

51 Su LC, Owen CA Jr, Zollman PE, Hardy RM. A defect of biliary excretion of copper in copper-laden Bedlington terriers. Am J Physiol 1982;243:G231-6.

52 Weber KM, Boston RC, Leaver DD. A kinetic model of copper metabolism in sheep. Aust J Agric Res 1980;31:773-90.

53 Peterson MG, Lazdins I, Danks DM, Mercer JFB. Cloning and sequencing of a sheep metallothionein cDNA. Eur J Biochem 1984:143:507-11

54 Rauch H. Toxic milk, a new mutation affecting copper metabolism in the mouse. $J$ Hered 1983;74:141-4.

55 Godwin-Austin RB, Robinson A, Evans K, Lascelles PT. An unusual neurological disorder of copper metabolism clinically resembling Wilson's disease but biochemically a distinct entity. $J$ Neurol Sci 1978;39:85-98.

56 Willvonseder R, Goldstein NP, McCall JT, Yoss RE, Tauze WN. A hereditary disorder with dementia, spastic dysarthria, vertical eye movement paresis, gait disturbance, splenomegaly and abnormal copper metabolism. Neurology (Minneap) 1973;23:1039-49.

57 Moynahan EJ. Acrodermatitis enteropathica: a lethal inherited human zinc deficiency disorder. Lancet 1974;ii:399-400.

58 Brummerstedt E, Basse A, Aagsted T, Andresen E. Animal model, lethal trait A46 in cattle (hereditary parakeratosis, hereditary thymic hypoplasia, hereditary zinc deficiency). Am J Pathol 1977;87:725-8.

59 Piletz JE, Ganschow RE. Zinc deficiency in murine milk underlies expression of the lethal milk (lm) mutation. Science 1978;199:181-3.

(x) Zimmerman AW, Hambridge KM, Lepow ML, Greenberg RD Stover ML, Casey CE. Symptomatic zinc deficiency in breastfed premature infants: evidence for a defect in mammary zinc secretion. Pediatrics 1982;69:176-83.

61 Johnson JL, Wand WR, Kajagopalan KV, Duren M, Beemer FA, Wadman SK. Inborn errors of molybdenum metabolism: combined deficiencies of sulfite oxidase and xanthine dehydrogenase in a patient lacking the molbydenum cofactor. Proc Natl Acad Sci USA 1980;77:3715-9.

Correspondence and requests for reprints to Professor D M Danks, Birth Defects Research Institute, Royal Children's Hospital Research Foundation, Flemington Road, Parkville, Victoria 3052, Australia. 